\title{
Genetic Variability, Association and Path Analysis in Indian Mustard [Brassica juncea (L.) Czern \& Coss.] for Yield and its Component Traits
}

\author{
Saikrishna Akoju ${ }^{*}$, B. Arunkumar², P. H. Kuchanur², \\ Hasan Khan ${ }^{3}$ and Ayyanagouda Patil ${ }^{4}$ \\ ${ }^{1}$ Dept. of Genetics and Plant Breeding, ${ }^{4}$ Dept. of Molecular Biology \& Agriculture \\ Biotechnology, College of Agriculture, Raichur, India \\ ${ }^{2}$ Dept. of Genetics and Plant Breeding, College of Agriculture, Bheemarayanagudi, India \\ ${ }^{3}$ Dept. of Genetics and Plant Breeding, College of Agriculture, Kalaburagi, India \\ *Corresponding author
}

\section{A B S T R A C T}

\begin{tabular}{l} 
Ke y w o r d s \\
Indian mustard, \\
Path coefficient \\
analysis, \\
Brassica juncea \\
\hline Article Info \\
$\begin{array}{l}\text { Accepted: } \\
12 \text { October } 2020 \\
\text { Available Online: } \\
10 \text { November } 2020\end{array}$ \\
\hline
\end{tabular}

A field experiment was conducted to estimate the genetic variability, trait association and path coefficient analysis among the Indian mustard genotypes during rabi, 2019. Analysis of variance revealed the mean sum of squares due to genotypes was highly significant for all the characters studies indicating the existence of ample variability among the genotypes studied. The high GCV and PCV observed for number of siliquae per plant and secondary branches per plant indicated the influence of environment on the expression of these characters were at minimum level. High heritability was recorded for character 1000 -seed weight and siliqua length, moderate heritability observed for days to $50 \%$ flowering and days to physiological maturity revealed the presence of additive gene action and minimum influence of environment in expression of these characters. High heritability estimates in broad sense coupled with low genetic advance as percent of mean was observed for siliqua length and 1000-seed weight indicated presence of non-additive gene action and provide limited scope for improvement through selection. Results of genotypic and phenotypic correlation coefficient revealed that seed yield per plant had significant positive correlation with plant height at genotypic level. However, seed yield per plant recorded negative correlation with days to $50 \%$ flowering at both levels but was significant at genotypic level.

\section{Introduction}

Indian mustard [Brassica juncea (L.) Czern \& Coss.] is one of the most important oilseed crops and stands second in both acreage and production of rapeseed and mustard in Asia. In India, Rapeseed and mustard occupied second position among the oilseed crops with an area and production of 6.23 million hectares and 9.34 million tons, respectively during 2018-19 (Anon, 2019). Prominent states growing mustard in India are Rajasthan, Uttar Pradesh, Haryana, Madhya Pradesh and Gujarat which contribute more than 80 per cent in area and production. 
Every breeder's first and foremost objective is to enhance the productivity through the varietal development programme which totally depends upon the genetic variability present in the available germplasm/breeding material of a particular crop. The assessment of various genetic parameters like genotypic coefficient of variance, phenotypic coefficient of variance, heritability and genetic advance are pre-requisite for the effective selection programme. Seed yield is a complex character and is usually controlled by non-additive gene actions and it is not only influenced by a few morphological characters which are governed by many genes, but also environment to a great extent.

Understanding the association between yield and its components is of paramount importance for making the best use of these relationships in selection (Sarawgi et al., 1997). The path coefficient analysis helps breeders to explain direct and indirect effects, and hence been extensively used in breeding experiments in different crop species (Ali et al., 2003; Akbar et al., 2003). Therefore, the present investigation was undertaken to assess the genetic variability, trait association, and path coefficient analysis in Indian mustard.

\section{Materials and Methods}

\section{Experimental material and location}

The experimental material consisted of 38 mustard genotypes including checks. These genotypes were evaluated during rabi 201920 at the experimental block, College of Agriculture, Bheemarayanagudi, University of Agricultural Sciences Raichur following randomized block design with three replications. Each genotype was sown in three rows of $3 \mathrm{~m}$ length with row to row and plant to plant spacing of $0.45 \mathrm{~m}$ and $0.10 \mathrm{~m}$ respectively. All the recommended packages of practices were followed to raise a healthy crop. Data on 10 traits were recorded on five randomly selected competitive plants from each genotype.

\section{Statistical analysis}

The statistical data of sampled plants were averaged to get mean values. The character means for each replication were then utilized for various statistical analyses following standard usual statistical procedure adopted to calculate mean, range, standard error, coefficient of variation and critical difference using Windostat version 9.2. Based on means and variances, different genetic parameters were calculated.

The analysis of variance (ANOVA) was calculated as per the procedure given by Panse and Shukatme (1967). Phenotypic and genotypic variances were estimated by using the formula given by Johnson et al., (1955). Genotypic and phenotypic coefficients of variation were estimated by using the formula (Burton, 1952). Broad sense heritability was calculated by using the formula suggested by Singh and Chaudhary (1985). Genetic advance was estimated by using the formula recommended by Allard (1960). Genetic advance in per cent of mean was estimated by the formula given by Comstock and Robinson (1952).

\section{Results and Discussion}

\section{Analysis of variance}

Analysis of variance (ANOVA) revealed that the mean sum of squares due to genotypes were highly significant for all the characters studies indicating the existence of ample variability among the genotypes studied (Table 1). This finding was in confirmation with the findings of Singh et al., (2013), Tripathi et al., (2013) and Shekhawat et al., (2014). 


\section{Genotypic and phenotypic coefficient of variation}

Genetic parameters of variation for seed yield and its components in Indian mustard are presented in Table 2. Genotypic coefficient of variation and phenotypic coefficient of variation were categorized as low (less than $10 \%)$, moderate (10-20\%) and high (more than $20 \%$ ) as suggested by Sivasubramanium and Madhavamenon (1973). Phenotypic coefficients of variation (PCV) in general, were higher in magnitude than the genotypic coefficient of variation (GCV) indicating that all characters under investigation were influenced by environmental factors. Characters, siliquae per plant $(38.71 \%$, $56.39 \%$ ) and secondary branches per plant $(20.03 \%, 38.16 \%)$ recorded the high GCV and PCV estimates while, days to physiological maturity exhibited lower magnitude of coefficient at both GCV $(04.74 \%)$ and PCV $(06.21 \%)$ levels. The high GCV and PCV estimates indicated that the minimum influence of environment and lower magnitude of GCV and PCV revealed the fixation of recessive genes and thus increasing homozygosity within the genotype and breeders should go for source having high variability for improvement of these characters. Earlier, high GCV and PCV estimates were reported by Akbari and Niranjana (2015) for siliquae per plant, Lodhi et al., (2014), Singh et al., (2013) and Tripathi et al., (2013) for secondary branches per plant. Similarly, low GCV and PCV estimates for days to physiological maturity were reported by Singh et al., (2013), Lodhi et al., (2014) and Semahegn and Tesfaye (2016).

The moderate estimates of GCV and PCV were recorded for siliqua length $(12.72 \%$, $15.10 \%)$ and 1000 -seed weight (16.98\%, $17.72 \%)$. These results are in confirmation with the results obtained by Lodhi et al., (2014) and Singh et al., (2013) for siliqua length and Yadava et al., (2011) and Singh et al., (2013) for 1000-seed weight.

The characters days to $50 \%$ flowering $(08.54 \%, 10.51 \%)$, plant height $(09.01 \%$, $14.45 \%)$ and seeds per siliqua $(09.64 \%, 15.95$ $\%$ ) recorded low and moderate GCV and PCV estimates, respectively. Character primary branches per plant registered a moderate and high GCV (14.85\%) and PCV (29.86\%) estimates, respectively. Earlier, Hussain et al., (2016) reported low GCV and moderate PCV estimates while Lodhi et al., (2014) and Singh et al., (2013), respectively reported low GCV and moderate PCV estimates for days to $50 \%$ flowering. Similarly, Hussain et al., (2016), Lodhi et al., (2014) and Semahegn and Tesfaye (2016) reported low GCV whereas, Singh et al., (2016) and Tripathi et al., (2013) reported moderate PCV estimates for plant height. Hussain et al., (2016), Singh et al., (2013) and Yadava et al., (2011) observed low GCV whereas, moderate PCV estimates were reported by Lodhi et al., 2014, Singh et al., (2013) and Tripathi et al., (2013).

Moderate GCV and high PCV estimates were registered for number of primary branches and seed yield per plant. These results agree with Lodhi et al., (2014) and Singh et al., (2013) for number of primary branches. Singh et al., (2013) reported moderate GCV and high PCV estimates and Hussain et al., (2016) moderate GCV and Tripathi et al., (2013) high PCV for seed yield per plant.

\section{Heritability and genetic advance}

An attempt was made to estimate the heritability in broad sense by variance component analysis in the present investigation. The prediction regarding this aspect was made based on percentage viz., low $(<50 \%)$, moderate $(50-70 \%)$ and high $(>70 \%)$ as suggested by Robinson (1966). High heritability was recorded for 1000-seed 
weight $(91.80 \%)$ followed by siliqua length $(71.00 \%)$. Higher heritability values revealed the presence of additive gene action and minimum influence of environment in expression of these characters. Selection based on these characters would be more effective compared to other characters, as it is an exploitable amount of variation. These findings are in line with the results of Singh et al., (2013) for both the characters, Tripathi et al., (2013) for 1000-seed weight and Lodhi et al., (2014) for siliqua length.

The moderate heritability was observed for the character days to $50 \%$ flowering $(66.00 \%)$ and days to physiological maturity $(58.30 \%)$. However, the characters, siliquae per plant (47.10\%), plant height $(38.90 \%)$, seeds per siliqua $(36.50 \%)$, secondary branches per plant $(27.60 \%)$, primary branches per plant $(24.70 \%)$ and seed yield per plant $(16.70 \%)$ registered lower estimates of heritability. Lower heritability estimates indicate that these characters are governed by poly genes and progress in selection for these characters is generally slow as environmental influence is more in expression of such characters. These results are in confirmation with results of Hussain et al., (2016) and Tripathi et al., (2013) for days to $50 \%$ flowering and Lodhi et al., (2014) and Tripathi et al., (2013) for days to physiological maturity. Similarly, Yadava et al., (2011) observed lower estimates of heritability for siliquae per plant, plant height, seeds per siliqua, secondary branches per plant, primary branches per plant and seed yield per plant. Hussain et al., (2016) reported lower estimates of heritability for plant height and siliquae per plant. Lower heritability estimates were reported by Singh et al., (2013) for primary and secondary branches per plant.

The heritability value alone provides no information on the amount of genetic improvement that would be possible from selection of superior genotypes and character exhibiting high heritability may not necessarily give high genetic advance. Therefore, knowledge about genetic advance coupled with heritability is most useful. The magnitude of genetic advance as percentage of mean was categorized as high (>20\%), moderate $(10 \%-20 \%)$ and low $(<10 \%)$. Genetic advance as percentage of mean was observed high for siliquae per plant (207.22\%) and moderate level for plant height (15.69\%). While, rest of the characters viz., days to $50 \%$ flowering $(07.15 \%)$, days to physiological maturity $(06.69 \%)$, secondary branches per plant $(02.12 \%)$, seed yield per plant $(01.86 \%)$, seeds per siliqua $(01.33 \%)$, 1000 -seed weight $(01.27 \%)$, siliqua length $(01.02 \%)$ and primary branches per plant $(0.54 \%)$ recorded lower estimates. Earlier, Semahegn and Tesfaye (2016) reported lower estimates of GAM for days to $50 \%$ flowering, primary branches per plant, secondary branches per plant and seed yield per plant, Tripathi et al., (2013) for days to 50\% flowering and days to physiological maturity and moderate GAM for plant height. Lower estimates of GAM for were also reported by Hussain et al., (2016) for days to physiological maturity, siliqua length and 1000-seed weight, Tiwari et al., (2017) reported low and high GAM estimates respectively, for seeds per siliqua and siliquae per plant.

Panse and Shukatme (1954) stated that if nonadditive gene action is involved in controlling a character, then character will show high heritability but low genetic advance whereas, if governed by additive gene action, heritability and genetic advance would be high. In the present investigation, high heritability estimates in broad sense coupled with low genetic advance as percent of mean was observed for siliqua length and 1000-seed weight indicating the presence of non-additive gene action and provide limited scope for 
improvement through selection while, siliquae per plant recorded low heritability and high genetic advance as percent of mean.

Moderate estimates of heritability with lower genetic advance as percentage of mean values were recorded for days to $50 \%$ flowering, days to physiological maturity. Plant height registered low heritability and moderate genetic advance as percentage of mean. Heritability and genetic advance as percentage of mean values for primary branches, secondary branches, seeds per siliqua and seed yield per plant were low. The results of present investigation are in line with findings of Swarnakar et al., (2002) for days to $50 \%$ flowering, Lodhi et al., (2014) for days to physiological maturity, Singh et al., (2011) for plant height, Singh et al., (2013) and Kumar et al., (2013) for primary branches per plant, Singh et al., (2013) and Mohan (2017) for secondary branches per plant, Kumar and Singh (2013) for seeds per siliqua, Singh et al., (2013) for siliqua length and Semahegn and Tesfaye (2016) for 1000-seed weight.

\section{Phenotypic and genotypic correlation coefficients}

Correlation coefficient analysis is a statistical measure which is used to find out the degree and direction of association between two or more variables. Information on the degree and magnitude of association between characters is of prime importance for the breeder to initiate any selection plan. Phenotypic and genotypic correlation coefficients for all possible combination of characters are presented in (Table 3). In general, the genotypic correlation coefficients were higher in magnitude than phenotypic correlation coefficients.

Days to $50 \%$ flowering registered significant positive correlation with days to physiological maturity (0.543: 0.842), number of primary branches per plant (0.345: 0.745) and number of secondary branches per plant (0.422: 0.972) at both genotypic and phenotypic levels. However, it exhibited significant but negative correlation with Seeds per siliqua (0.212) and Seed yield per plant (-0.705) at phenotypic and genotypic levels, respectively. Days to physiological maturity registered significant positive correlation with primary branches per plant (0.350) at phenotypic level and with Secondary branches per plant (0.390: 0.950) at both genotypic and phenotypic levels.

Plant height registered significant positive correlation with primary branches per plant (0.344) and seed yield per plant (0.708) at genotypic level only. Primary branches per plant registered significant positive correlation with secondary branches per plant (0.793), siliquae per plant (0.295) and siliqua length (0.299) at phenotypic level and significant but negative correlation with seed yield per plant $(-0.344)$ at genotypic level only. Secondary branches per plant registered significant positive correlation with siliquae per plant (0.347) and siliqua length (0.351) at phenotypic level and significant but negative correlation with seed yield per plant $(-0.760)$ at genotypic level only.

Siliquae per plant registered significant negative correlation with siliqua length (0.280: -0.694$)$ and 1000 -seed weight (-0.368: $-0.600)$ at both phenotypic and genotypic levels and with seeds per siliqua (-0.515) at genotypic level only. Seeds per siliqua plant registered significant positive correlation with siliqua length (0.567: 0.780) at phenotypic and genotypic levels and only at phenotypic level with 1000-seed weight (0.206). Siliqua length registered significant positive correlation with 1000-seed weight (0.551: 0.682) at both phenotypic and genotypic levels. 
Table.1 Analysis of variance for seed yield and its component traits in Indian mustard genotypes

\begin{tabular}{|c|c|c|c|c|c|c|c|c|c|c|c|}
\hline \multirow{2}{*}{$\begin{array}{l}\text { Source of } \\
\text { Variation }\end{array}$} & \multirow{2}{*}{$\begin{array}{l}\text { Degrees } \\
\text { of } \\
\text { freedom }\end{array}$} & \multicolumn{10}{|c|}{ Mean Sum of Squares } \\
\hline & & $\begin{array}{l}\text { Days to } \\
50 \% \\
\text { flowering } \\
\text { (d) }\end{array}$ & $\begin{array}{c}\text { Days to } \\
\text { physiological } \\
\text { maturity (d) }\end{array}$ & $\begin{array}{l}\text { Plant } \\
\text { height } \\
(\mathrm{cm})\end{array}$ & $\begin{array}{c}\text { Primary } \\
\text { branches } \\
\text { per plant } \\
\text { (no.) }\end{array}$ & $\begin{array}{c}\text { Secondary } \\
\text { branches } \\
\text { per plant } \\
\text { (no.) }\end{array}$ & $\begin{array}{l}\text { Siliquae } \\
\text { per plant } \\
\text { (no.) }\end{array}$ & $\begin{array}{c}\text { Seeds } \\
\text { per } \\
\text { siliqua } \\
\text { (no.) }\end{array}$ & $\begin{array}{l}\text { Siliqua } \\
\text { length } \\
(\mathrm{cm})\end{array}$ & $\begin{array}{c}1000- \\
\text { seed } \\
\text { weight } \\
(\mathrm{g})\end{array}$ & $\begin{array}{l}\text { Seed } \\
\text { yield per } \\
\text { plant }(g)\end{array}$ \\
\hline Genotype & 2 & $64.10^{* *}$ & $67.24^{* *}$ & $682.98^{* *}$ & $1.69^{* *}$ & $21.61^{* *}$ & $88510.35^{* *}$ & $5.47^{* *}$ & $1.18^{* *}$ & $1.28^{* *}$ & $38.89^{*}$ \\
\hline Replication & 37 & 32.31 & 134.53 & 963.05 & 2.03 & 627.96 & 72216.05 & 0.04 & 0.49 & 0.13 & 94.88 \\
\hline Error & 74 & 09.37 & 12.94 & 234.90 & 0.85 & 10.09 & 24092.31 & 2.00 & 0.14 & 0.03 & 24.25 \\
\hline
\end{tabular}

Note: * and ** significant at 5 and 1 per cent level of probability, respectively

Table.2 Genetic variability parameters for seed yield and its component traits in Indian mustard genotypes

\begin{tabular}{|c|c|c|c|c|c|c|c|c|c|}
\hline \multirow[t]{2}{*}{ Genetic Parameter } & \multicolumn{2}{|c|}{ Range } & \multirow[t]{2}{*}{ Mean } & \multicolumn{3}{|c|}{ Coefficient of variation } & \multirow{2}{*}{$\begin{array}{c}\text { Heritability } \\
\text { (broad sense) }\end{array}$} & \multirow{2}{*}{$\begin{array}{c}\text { Genetic } \\
\text { Advancement }\end{array}$} & \multirow{2}{*}{$\begin{array}{c}\text { Genetic } \\
\text { Advance as } \\
\text { per cent of } \\
\text { mean }\end{array}$} \\
\hline & Minimum & Maximum & & GCV & PCV & ECV & & & \\
\hline Days to $50 \%$ flowering (d) & 43.00 & 60.00 & 49.96 & 08.54 & 10.51 & 06.13 & 66.00 & 14.31 & 07.15 \\
\hline $\begin{array}{l}\text { Days to physiological } \\
\text { maturity }(d)\end{array}$ & 80.00 & 98.00 & 89.68 & 04.74 & 06.21 & 04.01 & 58.30 & 07.46 & 06.69 \\
\hline Plant height (cm) & 108.00 & 168.00 & 135.62 & 09.01 & 14.45 & 11.30 & 38.90 & 11.57 & 15.69 \\
\hline $\begin{array}{l}\text { Primary branches per plant } \\
\text { (no.) }\end{array}$ & 02.00 & 05.00 & 03.56 & 14.85 & 29.86 & 25.91 & 24.70 & 15.22 & 0.54 \\
\hline $\begin{array}{l}\text { Secondary branches per plant } \\
\text { (no.) }\end{array}$ & 06.00 & 17.00 & 09.78 & 20.03 & 38.16 & 32.47 & 27.60 & 21.67 & 02.12 \\
\hline Siliquae per plant (no.) & 209.00 & 1089.00 & 378.54 & 38.71 & 56.39 & 41.00 & 47.10 & 54.74 & 207.22 \\
\hline Seeds per siliqua (no.) & 07.00 & 14.00 & 11.14 & 09.64 & 15.95 & 12.71 & 36.50 & 11.99 & 01.33 \\
\hline Siliqua length $(\mathrm{cm})$ & 01.40 & 05.32 & 04.63 & 12.72 & 15.10 & 08.13 & 71.00 & 22.07 & 01.02 \\
\hline 1000-seed weight $(\mathrm{g})$ & 01.40 & 04.88 & 03.80 & 16.98 & 17.72 & 05.07 & 91.80 & 33.52 & 01.27 \\
\hline Seed yield per plant (g) & 04.56 & 20.10 & 11.36 & 19.43 & 47.49 & 43.33 & 16.70 & 16.38 & 01.86 \\
\hline
\end{tabular}

Note: $\mathrm{GCV}=$ Genotypic coefficient of variation, $\mathrm{PCV}=$ Phenotypic coefficient of variation and ECV= Environmental coefficient of variation 
Table.3 Phenotypic and genotypic correlation coefficients for seed yield and its component traits in Indian mustard genotypes

\begin{tabular}{|c|c|c|c|c|c|c|c|c|c|c|}
\hline Character & & $\begin{array}{c}\text { Days to } \\
\text { physiological } \\
\text { maturity }\end{array}$ & $\begin{array}{l}\text { Plant } \\
\text { height }\end{array}$ & $\begin{array}{l}\text { Primary } \\
\text { branches } \\
\text { per plant }\end{array}$ & $\begin{array}{c}\text { Secondary } \\
\text { branches } \\
\text { per plant }\end{array}$ & $\begin{array}{l}\text { Siliquae } \\
\text { per plant }\end{array}$ & $\begin{array}{l}\text { Seeds per } \\
\text { siliqua }\end{array}$ & $\begin{array}{l}\text { Siliqua } \\
\text { length }\end{array}$ & $\begin{array}{l}\text { 1000-seed } \\
\text { weight }\end{array}$ & $\begin{array}{l}\text { Seed yield } \\
\text { per plant }\end{array}$ \\
\hline \multirow{2}{*}{$\begin{array}{l}\text { Days to } 50 \% \\
\text { flowering }\end{array}$} & $\mathrm{P}$ & $0.543 * * *$ & -0.079 & $0.345^{* *}$ & $0.422 * *$ & 0.083 & $-0.212^{*}$ & 0.032 & 0.024 & -0.298 \\
\hline & $\mathrm{G}$ & $0.842 * *$ & -0.213 & $0.745^{* *}$ & $0.972 * *$ & 0.245 & -0.219 & 0.066 & 0.009 & $-0.705^{* *}$ \\
\hline \multirow{2}{*}{$\begin{array}{l}\text { Days to } \\
\text { physiological } \\
\text { maturity }\end{array}$} & $\mathrm{P}$ & & 0.158 & $0.350 * *$ & $0.390 * *$ & 0.070 & -0.079 & 0.088 & 0.117 & -0.150 \\
\hline & $\mathrm{G}$ & & 0.224 & 1.084 & $0.950 * *$ & 0.158 & $-0.0003 \mathrm{~s}$ & 0.202 & 0.172 & -0.115 \\
\hline \multirow[t]{2}{*}{ Plant height } & $\mathrm{P}$ & & & 0.058 & -0.003 & -0.04 & 0.041 & 0.078 & -0.02 & 0.304 \\
\hline & G & & & $0.344^{*}$ & -0.163 & -0.113 & 0.036 & 0.111 & -0.019 & $0.708 * *$ \\
\hline \multirow{2}{*}{$\begin{array}{l}\text { Primary branches } \\
\text { per plant }\end{array}$} & $\mathrm{P}$ & & & & $0.793 * *$ & $0.295 * *$ & 0.071 & $0.299 * *$ & 0.029 & 0.319 \\
\hline & G & & & & 1.030 & 0.228 & -0.144 & 0.272 & 0.071 & $-0.344^{*}$ \\
\hline \multirow{2}{*}{$\begin{array}{l}\text { Secondary branches } \\
\text { per plant }\end{array}$} & $\mathrm{P}$ & & & & & $0.347 * *$ & 0.155 & $0.351 * * *$ & 0.088 & 0.254 \\
\hline & G & & & & & 0.010 & -0.064 & $0.345^{*}$ & 0.195 & $-0.760 * *$ \\
\hline \multirow[t]{2}{*}{ Siliquae per plant } & $\mathrm{P}$ & & & & & & -0.092 & $-0.280 * *$ & $-0.368 * *$ & 0.452 \\
\hline & G & & & & & & $-0.515 * *$ & $-0.694 * *$ & $-0.600 * *$ & 0.32 \\
\hline \multirow[t]{2}{*}{ Seeds per siliqua } & $\mathrm{P}$ & & & & & & & $0.567 * *$ & $0.206 *$ & 0.241 \\
\hline & G & & & & & & & $0.780 * *$ & 0.318 & -0.062 \\
\hline \multirow[t]{2}{*}{ Siliqua length } & $\mathrm{P}$ & & & & & & & & $0.551 * *$ & 0.036 \\
\hline & G & & & & & & & & $0.682 * *$ & -0.188 \\
\hline \multirow[t]{2}{*}{1000 -seed weight } & $\mathrm{P}$ & & & & & & & & & 0.021 \\
\hline & G & & & & & & & & & 0.017 \\
\hline
\end{tabular}

Note: P= Phenotypic level, G= Genotypic level, * and ** significant at 5 and 1 per cent level of probability, respectively 
Table.4 Phenotypic path matrix for seed yield and its component traits in Indian mustard genotypes

\begin{tabular}{|c|c|c|c|c|c|c|c|c|c|}
\hline Character & $\begin{array}{c}\text { Days to } \\
50 \% \\
\text { flowering }\end{array}$ & $\begin{array}{c}\text { Days to } \\
\text { physiological } \\
\text { maturity }\end{array}$ & $\begin{array}{l}\text { Plant } \\
\text { height }\end{array}$ & $\begin{array}{l}\text { Primary } \\
\text { branches } \\
\text { per plant }\end{array}$ & $\begin{array}{c}\text { Secondary } \\
\text { branches } \\
\text { per plant }\end{array}$ & $\begin{array}{l}\text { Siliquae } \\
\text { per plant }\end{array}$ & $\begin{array}{l}\text { Seeds per } \\
\text { siliqua }\end{array}$ & $\begin{array}{l}\text { Siliqua } \\
\text { length }\end{array}$ & $\begin{array}{l}\text { 1000-seed } \\
\text { weight }\end{array}$ \\
\hline $\begin{array}{l}\text { Days to } 50 \% \\
\text { flowering }\end{array}$ & -0.288 & -0.156 & 0.022 & -0.099 & -0.127 & -0.023 & 0.061 & -0.009 & -0.007 \\
\hline $\begin{array}{l}\text { Days to physiological } \\
\text { maturity }\end{array}$ & -0.118 & -0.219 & -0.034 & -0.076 & -0.085 & -0.015 & 0.017 & -0.019 & -0.025 \\
\hline Plant height & -0.026 & 0.052 & 0.331 & 0.019 & -0.001 & -0.013 & 0.013 & 0.025 & -0.006 \\
\hline $\begin{array}{l}\text { Primary branches per } \\
\text { plant }\end{array}$ & 0.118 & 0.120 & 0.019 & 0.345 & 0.273 & 0.101 & 0.024 & 0.103 & 0.009 \\
\hline $\begin{array}{l}\text { Secondary branches } \\
\text { per plant }\end{array}$ & 0.033 & 0.029 & -0.002 & 0.060 & 0.076 & 0.026 & 0.011 & 0.026 & 0.006 \\
\hline Siliquae per plant & 0.036 & 0.030 & -0.017 & 0.128 & 0.151 & 0.435 & -0.040 & -0.121 & -0.16 \\
\hline Seeds per siliqua & -0.052 & -0.019 & 0.010 & 0.017 & 0.038 & -0.022 & 0.246 & 0.139 & 0.050 \\
\hline Siliqua length & -0.008 & -0.024 & -0.021 & -0.082 & -0.096 & 0.077 & -0.156 & -0.276 & -0.152 \\
\hline 1000-seed weight & 0.007 & 0.035 & -0.006 & 0.008 & 0.026 & -0.112 & 0.062 & 0.168 & 0.305 \\
\hline Seed yield per plant & -0.298 & -0.150 & 0.304 & 0.319 & 0.254 & 0.452 & 0.241 & 0.036 & 0.021 \\
\hline r value & 0.086 & 0.032 & 0.100 & 0.110 & 0.019 & 0.196 & 0.059 & -0.010 & 0.006 \\
\hline
\end{tabular}


In the present investigation, seed yield per plant registering significant and positive correlation only with plant height at genotypic level indicates that direct selection for seed yield would be effective. This finding agrees with results of Akbari and Niranjana (2015) and Afrin et al., (2011).

However, seed yield per plant recording negative correlation with days to $50 \%$ flowering at both levels signifies the fact that early flowering leads early maturity and reducing the duration of photosynthates accumulation in the plants and resulting in reduced yield levels. Previously, Shekhawat et al., (2014) reported negative correlation between seed yield per plant and days to $50 \%$ flowering at genotypic level. Character, days to $50 \%$ flowering registered significant positive correlation with days to physiological maturity at both genotypic and phenotypic level indicating that earlier the flowering shorter would be maturity duration. These results confirm the earlier findings of Ara et al., (2013), Bind et al., (2014) and Shekhawat et al., (2014).

Plant height and primary branches per plant have significant and positive correlation at genotypic level indicating the taller the plant more will be the branches. These results are in accordance with findings of Bind et al., (2014), Akbari and Niranjana (2015) and Afrin et al., (2011). Significant and positive association between seeds per siliqua and siliqua length revealed the fact that larger the siliqua length greater will be seed number. 1000-seed weight and siliqua length have significant and positive correlation at genotypic and phenotypic level.

These findings are in accordance with reports of Bind et al., (2014) at genotypic and phenotypic levels and Tantuway et al., (2018) at genotypic level only.

\section{Phenotypic path coefficient analysis}

\section{Direct effects}

Results of phenotypic path coefficient exhibited positive direct contribution of plant height (0.331), primary branches per plant $(0.345)$, siliquae per plant $(0.435)$, seeds per siliqua (0.246) and 1000-seed weight (0.305) towards seed yield per plant (Table 4). These results indicate the importance of these characters in governing seed yield per plant. The positive direct contribution of these characters observed for seed plant in this study are in confirmation with findings of Mahak et al., (2011) for plant height; Bind et al., (2014) for seeds per siliqua; Mahak et al., (2011) and Bind et al., (2014) for 1000-seed weight; Bind et al., (2014) for primary branches per plant.

Characters, days to $50 \%$ flowering, days to physiological maturity and siliqua length had negative direct effect on seed yield per plant. These results are in confirmation with findings of, Shekhawat et al., (2014) for days to 50\% flowering; Bind et al., (2014) and Mahak et al., (2011) for days to physiological maturity and Iqbal et al., (2014) for siliqua length.

\section{Indirect effects}

Days to flowering exhibited highest positive effect via primary branches per plant (0.118) and lowest via 1000-seed weight (0.007). Similarly, highest negative effect was exhibited via siliqua length (-0.008) and lowest via days to physiological maturity (0.118) Days to physiological maturity exhibited highest positive effect via number of primary branches per plant (0.120) and lowest via number of secondary branches per plant (0.029). Similarly, highest negative effect via siliqua length (-0.024) and lowest via days to $50 \%$ flowering $(-0.156)$ was 
recorded. Plant height recorded highest positive effect via days to $50 \%$ flowering $(0.022)$ and lowest via seeds per siliqua (0.010). Highest negative effect was revealed by secondary branches per plant $(-0.002)$ and lowest by days to physiological maturity ($0.034)$.

Number of primary branches exhibited highest positive effects via siliquae per plant $(0.128)$ and lowest via 1000-seed weight (0.008) and highest negative effect via days to physiological maturity (-0.076) and lowest via days to $50 \%$ flowering $(-0.099)$. Number of secondary branches exhibited highest positive effect via primary branches per plant $(0.273)$ and lowest via 1000 -seed weight (0.026).

Highest negative effect was exhibited by plant height $(-0.001)$ and lowest by days to $50 \%$ flowering (-0.127). Number of siliquae per plant exhibited highest positive effect via siliqua length (0.077) and lowest via number of secondary branches (0.026) and highest negative effect via plant height $(-0.013)$ and lowest via 1000 -seed weight (-0.112).

Seeds per siliqua showed highest positive effect via 1000-seed weight (0.062) and lowest via number of secondary branches (0.011) similarly, highest negative effect via number of siliquae per plant $(-0.040)$ and lowest via siliqua length (-0.156). Siliqua length exhibited highest positive indirect effect via 1000-seed weight (0.168) and lowest via plant height (0.025) and highest negative effect by days to $50 \%$ flowering (0.009 ) and highest by number of siliquae per plant (-0.121). 1000-seed weight exhibited highest positive effect via seeds per siliqua (0.050) and lowest via secondary branches per plant (0.006) and highest negative effect via number of siliquae per plant $(-0.16)$ and lowest via days to $50 \%$ flowering $(-0.007)$ (Table 4).

\section{References}

Afrin, K. S., Bhuiyan, S. R. and Rahim, M. A., 2011, Assessment of genetic variation among advanced lines of Brassica napus (L.). Agronomski Glansik, 4(5): 201-226.

Akabari, V. R. and Niranjana, A., 2015, Genetic variability and trait association studies in Indian mustard (Brassica juncea). Int. J. Agric., 11(1): 35-39.

Akbar, M., Tariq, M., Yaqub, M., Anwar, M., Ali, M. and Iqbal, N., 2003, Variability, correlation and path coefficient studies in summer mustard [Brassica juncea (L.) Czern. \& Coss.]. Asian J. Pl. Sci., 2: 696-698.

Ali, N., Farzad, J., Jaferieh, Y. E. and Mýrza, M. Y., 2003, Relationship among yield components and selection criteria for yield improvement in winter rapeseed [Brassica napus (L.) Czern. \& Coss.]. Pak. J. Bot., 35: 167-174.

Allard, R. W., 1960, Principle of Plant Breeding. John Willey and Sons, Inc. New York, London.

Anonymous, 2019, Agriculture statistics at a glance, Ministry of Agriculture, New Delhi, India.

Ara, S., Afroz, S., Noman, M. S., Bhuiyan, M. S. R. and Zia, M. I. K., 2013, Variability, correlation and path analysis in $\mathrm{F}_{2}$ progenies of inter-varietal crosses of Brassica rapa. J. Environ. Sci. Nat. Resour., 6(1): 217 - 220.

Bind, D., Singh, D. and Dwivedi, V. K., 2014, Genetic variability and character association in Indian mustard [Brassica juncea (L.) Czern \& Coss.]. Agric. Sci. Dig., 34(3): $183-188$.

Burton, G. W., 1952, Quantitative inheritance in grasses. Pro. VI Int. Grassl. Cong., 277-283.

Comstock, R. E. and Robinson, H. F., 1952, Genetic parameters, their estimation and significance. Pro. VI Int. Grassl. Cong., 
1: 248-291.

Hussain, M. A., Hossain, M. S., Bhuiyan, M. S. R., Zeba, N. and Mohsin, S. M., 2016, Field performance and genetic analysis in some advanced lines of mustard (Brassica rapa L.). The Agriculturists, 14(1): 12-121.

Iqbal, M. S., Haque, M. S., Nath, U. K. and Hamim, I., 2014, Genetic diversity analysis of mustard germplasm based on phenotypic traits for selection of short duration genotypes. Int. J. Agric. Sci. Res., 3(8): 141-156.

Johnson, H. W., Robinson, H. F. and Comstock, R. E., 1955, Estimates of genetic and environmental variability in soybean. Agron. J., 47(7): 314-318.

Kumar, M. and Singh, S. P., 2013, Genetic variability, character association and path analysis for seed yield and its components in Indian mustard [Brassica juncea (L.) Czern \& Coss.]. Progress. Res., 8(2): 257-259.

Kumar, B., Pandey, A. and Singh, S. K., 2013, Genetic diversity for agromorphological and oil quality traits in Indian mustard [Brassica juncea (L.) Czern \& Coss.]. Bioscan, 8(3): 771-775.

Lodhi, B., Thakral, N. K., Avtar, R. and Singh, A., 2014, Genetic variability, character association and path analysis in Indian mustard (Brassica juncea L.). J. Oilseed Bra., 5(1): 26-31.

Mahak, S., Tomar, A., Mishra, C. N. and Srivastava, S. B. L., 2011, Genetic parameters and character association studies in Indian mustard. J. Oilseed Bra., 2(1): 35-38.

Mohan, S., Yadav, R. K., Tomar, A. and Singh, M., 2017, Utilization of selection parameters for seed yield and its contributed traits in Indian mustard [Brassica juncea (L.) Czern \& Coss.]. Pharma Innovation, 6(8): 306-309.

Panse, V. G. and Sukhatme, P. V., 1954, "Statistical Methods for Agricultural
Workers". $2^{\text {nd }}$ Edition, Indian Council of Agricultural Research, New Delhi.

Panse, V. G. and Sukhatme, P. V., 1967, "Statistical Methods for Agricultural Workers". 2nd Endorsement, ICAR Publication, New Delhi, India, 381.

Robinson, H. F., 1966, Quantitative genetics in relation to breeding of the centennial of mendalism. Indian J. Genet., 26: 171187.

Sarawgi, A. K., Rastogi, N. K. and Soni, D. K., 1997, Correlation and path analysis in rice accessions from Madhya Pradesh. Field Crops Res., 52: 161-167

Semahegn, Y. and Tesfaye, M., 2016, Variability, heritability and genetic advance analysis for some morphological characters in oilseed Brassica breeding lines. Mol. Pl. Breed., 7(20): 1-8.

Shekhawat, N., Jadeja, G. C., Singh, J. and Shekhawat, R. S., 2014, Character association studies among yield and its component characters in Indian mustard [Brassica juncea (L.) Czern \& Coss.]. Bioscan, 9(2): 685-688.

Singh, A., Avtar, R., Singh, D., Sangwan, O. and Balyan P., 2013, Genetic variability, character association and path analysis for seed yield and component traits under two environments in Indian mustard. J. Oilseed Bra., 4(1): 43-48.

Singh, A., Krishna, R., Singh, L. and Jeet, R., 2011, Heritability and genetic advance in Indian mustard [Brassica juncea (L.) Czern \& Coss.]. Curr. Adv. Agric. Sci., 3(1): 5253.

Singh, M., Tomar, A., Mishra, C. N. and Srivastava, S. B. L., 2016, Genetic parameters and character association studies in Indian mustard. J. Oilseed Bra., 1(1): 35-38.

Singh, R. K. and Chaudhary, B. D., 1985, Biometrical methods in quantitative genetic analysis. Kalyani Publishers, New Delhi. 
Sivasubramaniam, S. and Madhavamenon, P., 1973, Genotypic and phenotypic variability in rice. Madras Agric. J., 60(9-13): 1093-1096.

Swarnakar, G. B., Singh, M., Prasad, Lalta and Lallu, 2002, Analysis of heritability and genetic advance in relation to yield and its contributing traits in Indian mustard [Brassica juncea (L.) Czern \& Coss.]. Pl. Arch., 2(2): 305- 308.

Tantuway, G., Srivastava, K. and Tirkey, A., 2018, Character association and path analysis studies of yield \& yield attributing traits in Indian mustard [Brassica juncea (L.) Czern \& Coss.]. Pl. Arch., 18 (2): 2245-2251.

Tiwari, A. K., Singh, S. K., Tomar, A. and Singh, M., 2017, Heritability, genetic advance and correlation coefficient analysis in Indian mustard [Brassica juncea (L.) Czern \& Coss.]. J. Pharmacogn. Phytochem., 6(1): 356359.

Tripathi, N., Kumar, K. and Verma O. P., 2013, Genetic variability, heritability and genetic advance in Indian mustard [Brassica juncea (L.) Czern \& Coss.] for seed yield and it's contributing attributes under normal and saline/alkaline condition. Int. J. Sci. Res., 4(8): 983-985.

Yadava, D. K., Giri, S. C., Vignesh, M., Vasudev, S., Kumar Yadav, A., Dass, B., Singh, R., Singh, N., Mohapatra, T. and Prabhu, K. V., 2011, Genetic variability and trait association studies in Indian mustard (Brassica juncea). Indian J. Agric. Sci., 81(9): 712-716.

\section{How to cite this article:}

Saikrishna Akoju, B. Arunkumar, P. H. Kuchanur, Hasan Khan and Ayyanagouda Patil. 2020. Genetic Variability, Association and Path Analysis in Indian Mustard [Brassica juncea (L.) Czern \& Coss.] for Yield and its Component Traits. Int.J.Curr.Microbiol.App.Sci. 9(11): 13731384. doi: https://doi.org/10.20546/ijcmas.2020.911.162 